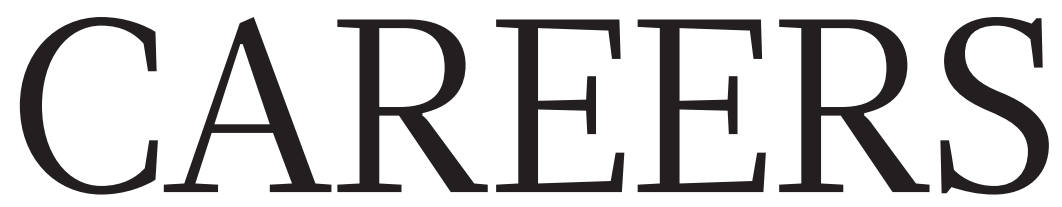

TRADE TALK Moving from lab work to regulatory affairs $\mathbf{p . 1 1 9}$
PUBLIC SPEAKING How to plan a two-minute pitch go.nature.com/xhy3kb
BECOMING FACULTY Hurdles to expect and overcome go.nature.com/x3fwwc

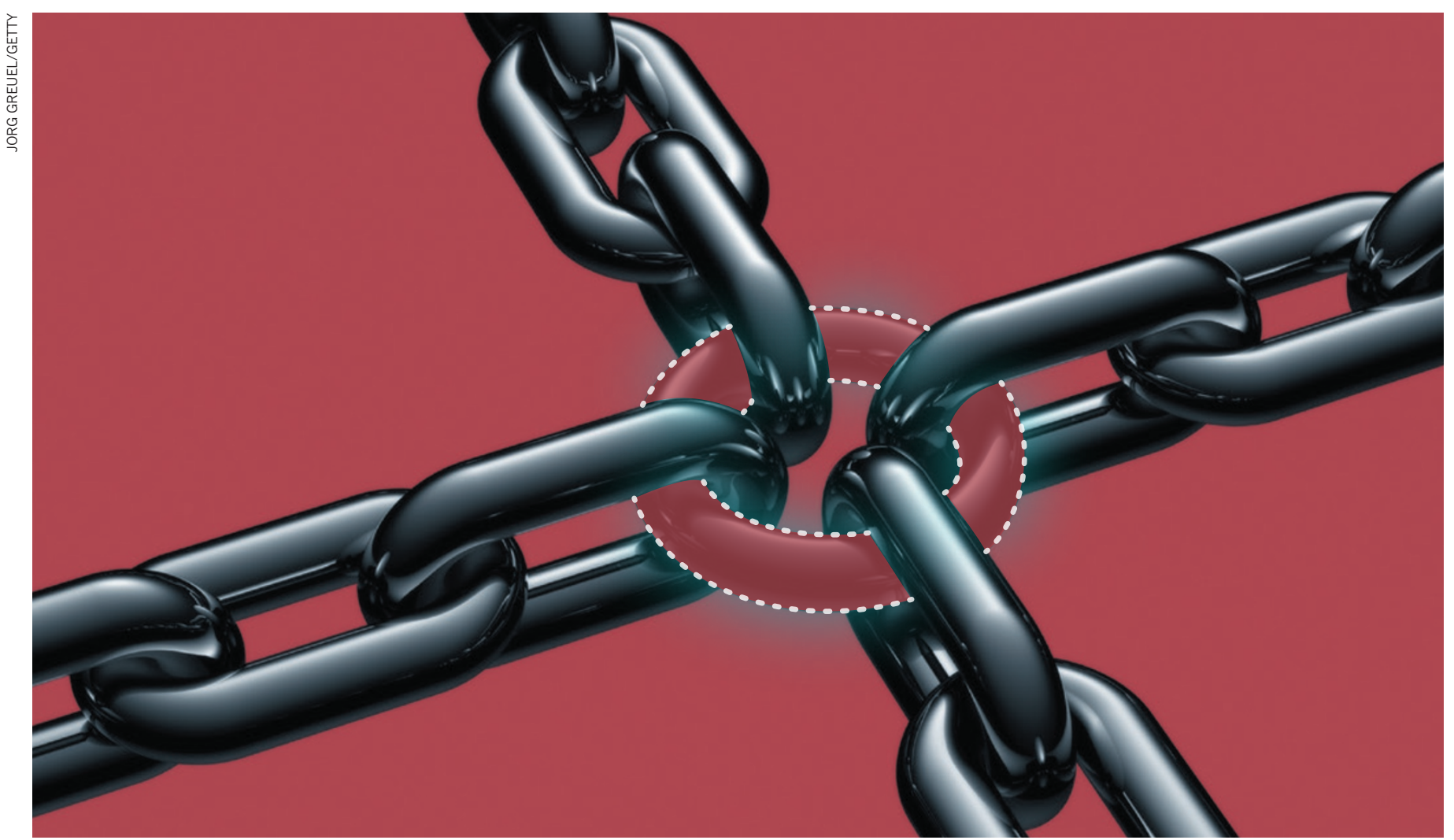

RESEARCH CONTINUITY

\title{
Be prepared
}

\section{When a key member of a team is lost, the work does not have to come to an end.}

\section{BY HANNAH HOAG}

$\mathrm{W}$ hen Michael Pisaric was two years into his $\mathrm{PhD}$, he travelled to Watson Lake in Canada with his supervisor, Julian Szeicz, and graduate student Tammy Karst-Riddoch, to collect sediment from several lakes in Yukon and in northern British Columbia. Szeicz was a geographer at Queen's University in Kingston, Canada, who worked on reconstructing ancient climates. The trio hoped that the samples would reveal how climate had influenced tree-line dynamics in the region over the past 10,000 years.

As they trudged through the snow and negotiated a series of switchbacks, a snow avalanche roared down the hill and covered them. When it cleared, Pisaric was buried up to his shoulders and there was no sign of Szeicz. Karst-Riddoch dug Pisaric out and they ran down the hillside to call the Royal Canadian Mounted Police, who recovered Szeicz's body later that day.

These sorts of tragedies are rare, devastating and hard to deal with. The loss of a principal investigator owing to an accident or illness can not only set junior lab members adrift emotionally, it can also put their careers in jeopardy. But they can establish ways to keep their careers from becoming unhinged (see 'Setback savers'). Collaborative networks can help to keep funding in place, and a hard look at the progress of their research and career path will help them to work out where to go next.

But first they must work through the emotional toll of the death or diagnosis. "You have to take care of yourself, and that may mean moving away from your work for an extended period of time," says Pisaric, who did not return to research for six months after the event. "Come back when you are comfortable, not because of the pressure from other people." When Pisaric did return, he avoided his $\mathrm{PhD}$ research. Instead, he busied himself with data from his master's degree on changes to the Siberian tree line over the past 10,000 years, later publishing two papers ${ }^{1,2}$. $\mathrm{He}$ found a new supervisor and a mentor and eventually returned to full speed.

When Tony Pawson, a cell biologist at the Lunenfeld-Tanenbaum Research Institute at Mount Sinai Hospital in Toronto, Canada, died unexpectedly in August 2013, his lab group consisted of about 30 people. "They 


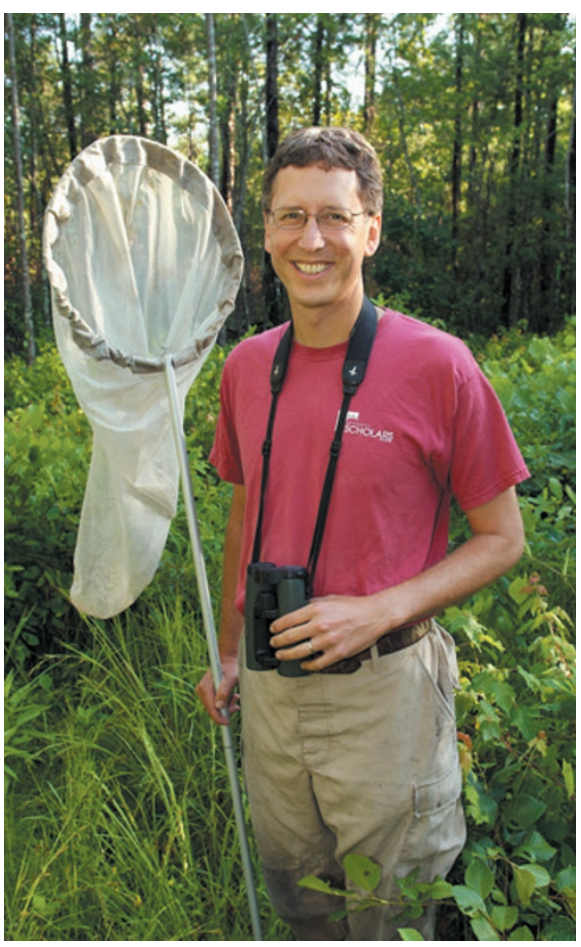

Nick Haddad says that his colleagues acted as a safety net when he had a debilitating accident.

- were in shock," says Jim Woodgett, the institute's director of research. They were referred to psychologists to address the grief and stress that they were experiencing; many had failed to recognize how dependent they were on this one person, he says.

It was stressful, recalls Greg Findlay, who now runs his own lab in embryonic stem-cell signalling at the University of Dundee, UK. "It was a terrible tragedy, yet we also had to think about, 'Where did our lives go from here?"' Those who fared best were the ones who had already formed professional relationships with other scientists, mostly senior researchers at their own or other institutions, who gave them lab space, advocated for resources and fought on their behalf to ensure that they had enough time to recover emotionally. The same was true for Pisaric and others who benefited from a mentor who looked out for their emotional wellbeing and helped them to secure the financial resources and academic support they needed to continue their PhD work.

\section{NETWORK BUILDERS}

Graduate students and postdocs can become wrapped up in the race for results and publications, and often do not make building these networks a priority. But even their own health problems can stall the publications and experiments that are crucial to building a career. Establishing ties within an institute - and outside its walls - is important for career development. Connections made at conferences and online can turn into fruitful collaborations and job opportunities - and a much-needed safety net should their lab have to shut down unexpectedly.

Nick Haddad, an ecologist at North Carolina State University in Raleigh, credits his collaborators for covering for him during the time that he was unable to work. He had just 4 days left to refine a paper with 25 coauthors when he had an accident that put him out of action for almost two months.

His collaborators contacted the journal editor and pulled together the pieces left dangling. The paper was eventually published in Science Advances ${ }^{3}$. Haddad sees the article as tangible evidence of his safety net. "I cannot remember being this excited about a paper, except maybe my first," he says. "We like to think of ourselves as independent scientists and academics, except that it is not really true. We are a community of scholars, and my own success is not mine, but the success of a group of people who are interacting and collaborating."

As well as collegial support, trainees need to ensure that their financial affairs are in order (see 'Control your assets'). Graduate students, especially, tend to be supported by their supervisor's funding. Pisaric, who is now a physical geographer at Brock University in St. Catharines, Canada, recalls that the initial response from the funding agency was to terminate Szeicz's grant and claw back the unused money. It was an enormous blow on top of all the other emotional stress he was experiencing. "I was left wondering," he says, "'how do I finish my PhD with no funding?"'

Research grants depend on the terms that the sponsor lays out in the funding agreement. Many of the grants from US and Canadian federal funding agencies are contracts between the agency and a laboratory's principal investigator. The agency's decision to support a

\section{SETBACK SAVERS}

\section{Beat the unexpected}

IIIness and death can catch people by surprise, but there are ways to mitigate some of the effects.

- Set up support networks. It is good to have advocates nearby, and connections outside your home turf are also important.

- Form good habits. Take detailed notes, scan them and, especially for field scientists, preserve an offsite copy. - Know where all the data related to your research is stored — and establish access to it early on.

- Have conversations with colleagues about your research and your career goals.

- Remember to take care of your own emotional health. H.H. project therefore rests on the track record of the scientists leading it, not just on the idea, so the grant can be terminated if the recipient is no longer able to carry out the research or to meet other requirements. Like other agencies, the US National Science Foundation tries to be flexible when a grantee needs to step back from a project, says Dana Topousis, acting head of the foundation's office of legislative and public "These affairs in Washington DC. In some cases, are human relationships, and there the project can be transferred to a coprincipal investigator. In the case of is always sympathy." prolonged absence owing to illness, these agencies have provisions in place that allow the principal investigator to postpone or transfer the grant to a colleague. "I know of individuals who have put their grants on hold for chemotherapy or to care for someone in their family who is very ill," says Judith Chadwick, assistant vice-president of research services at the University of Toronto. "These are human relationships, and there is always sympathy."

In Pisaric's case, his department encouraged him to draw up a budget that would allow him to complete crucial aspects of his research and cover conference expenses and lab costs, such as those related to sample analysis. The department then worked with the funding agency to secure some of the financial support he needed from Szeicz's grant.

\section{TIME FOR COMPROMISE}

But other grants, including those for infrastructure, or support that comes from industry, may not be as flexible. When his supervisor passed away in the third year of his $\mathrm{PhD}$ at the Kennedy Institute of Rheumatology at the University of Oxford, UK, Adam Cribbs found that his own stipend remained intact, but other funding in the lab disappeared. That meant he was no longer able to do some planned experiments with a price tag of close to $£ 10,000$ (US $\$ 15,654$ ), but with a few compromises still managed to finish his $\mathrm{PhD}$ on time.

Unexpected disasters can also bring truths to the surface and give trainees a chance to re-evaluate the direction of their careers. They may choose to move into another area of research or even away from science.

Marc Chrétien was six years into his $\mathrm{PhD}$ in laboratory medicine at the University of Toronto when his supervisor died of cancer. Chrétien had been developing a method to study the intracellular response of endothelial cells to the stress created by blood flow. He says that instead of one person stepping in, five departmental scientists tried to achieve consensus on the direction of his research and his readiness to write up his thesis. "Emotionally, I was completely drained and exhausted," he says. As a result, Chrétien decided to switch 


\section{SCIENTIFIC BEQUESTS}

\section{Control your assets}

When a principal investigator $(\mathrm{Pl})$ has to leave his or her job suddenly, there can be squabbles over who gets the samples. But the effects are likely to be lessened and easier to circumnavigate if labs have carefully catalogued all the specimens, reagents and technologies, such as transgenic mouse lines or proprietary imaging tools.

In many cases, these resources are considered the property of the institution, so starting early in their employment, PIs should make sure that they manage them in such a way that would give the rest of the research community access to them in the event of the Pl's absence.

Scientists who are not bound by intellectual-property policies should make a detailed inventory of the scientific assets they might wish to distribute, says Ron Weiss, a partner at the Massachusetts law firm Bulkley Richardson, who manages estates and estate planning for scientists and others. Ownership depends largely on the terms of the funding and on the investigator's contract, but some items may have been created or collected before the scientist joined the university or institute. "Understand the policies of your employment, and exactly what your relationship is. Usually you are an employee, but sometimes you are not. Scientists can leave a boatload of trouble if they don't adhere to the policies and someone else benefits at the expense of the institution that had the rights."

Scientists working at government laboratories or with private companies are unlikely to own much of their data. But those who work independently and who have taken steps to protect their intellectual property will probably have assigned all the rights to an entity such as a limited-liability corporation, says Weiss. In the event of the scientist's death, the entity could then be sold to a pre-chosen buyer, and the research materials could be bequeathed through a memorandum referenced in a will.

Another approach to managing specimens is to distribute the goods up front. Josh Drew, a lecturer at Columbia University in New York, studies the evolution and conservation of coral-reef fish across the southwestern Pacific Ocean. For his fieldwork, he collects fish, clips a small segment of gill for DNA analysis and stores the fish in formalin. Once home, he donates the specimens to the American Museum of Natural History in New York so that others can study them long after he has left academia.

Drew admits that when he started the scheme he had not been thinking of what would happen to the specimens if he died suddenly or had to cope with a longterm illness. But he recognizes that his actions would help to cover his students and colleagues if that should happen. Drew has placed a two-year moratorium on access to the samples so that he has time to publish his research. "If I don't publish within two years, that's on me," he says. H.H.

this confidence," he says. "I collaborated with quite a few people and found out my strengths and weaknesses."

Such experiences are difficult and traumatic, but there can also be constructive outcomes. "It changed me, I grew up, it made me a better scientist," says Cribbs. "If you don't ask for help you don't get it — and that can make the difference between finishing and not finishing." -

\section{Hannah Hoag is a freelance writer in Toronto, Canada.} ship in bioinformatics, which is designed to train biologists in computational biology. Although his interest in bioinformatics was spurred by his supervisor, he says that he probably would not have changed course so dramatically and sought additional training had he not become much more independent than his peers. "I'm not sure I would have tried something new if I hadn't developed
TRADE TALK Quality wrangler

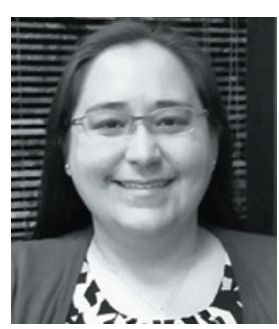

After finishing her postdoc in chemical biology at Stanford University, California, Leslie Cruz took a job in regulatory affairs at Alexza Pharmaceuticals in Mountain View, California. She explains how she continues to use the skills she learned in the laboratory.

\section{What does it take to leave the bench?}

The hardest thing for me was to realize that I wasn't happy. In graduate school, I would occasionally question my career path but was always led back to research in the laboratory.

\section{What changed?}

My postdoc adviser directed me to the university career office, which recommended Career Opportunities in Biotechnology and Drug Development (Harbor Laboratory, 2008). I read it cover to cover and took every quiz about how one's personality would be suited to different areas of the pharmaceutical industry. To my surprise, my results were the worst for discovery research and highest for regulatory affairs and project management.

\section{Does your role use your scientific training?}

I use it every day. I read a lot of 'quality documents' - regulatory submissions to establish that our pharmaceutical products are made using exacting procedures and have passed rigorous tests. I can see the trends in the data, read the graphs and methods and understand them.

\section{What lessons did you learn from the lab?}

It's not only what I learned but what I did: I wrote numerous grant applications. The important part of that was that I loved it, the reading and reviewing and documentation. That's what I do now, only with submission documents for regulatory agencies. The other part that I learned was working with people. At my job interview, people kept asking what I did outside of conducting experiments - they wanted to know that I had the skills to influence others. In my graduate programme, I was always the lab's contact for environmental-health and safety compliance, and worked with everyone to make sure that they were doing their training and paperwork. I had no idea that this would help me to get this job. I just did it because I enjoyed it.

\section{INTERVIEW BY MONYA BAKER}

This interview has been edited for length and clarity; see go.nature.com/vl1igx for more. 